Investeren in employability: Wiens verantwoordelijkheid?

Marijke Verbruggen, Anneleen Forrier, Lus Sels en An Bollen

DEPARTMENT OF MARKETING AND ORGANISATION STUDIES (MO) 


\title{
Investeren in employability: \\ Wiens verantwoordelijkheid?
}

\author{
Marijke Verbruggen \\ Anneleen Forrier \\ Luc Sels \\ An Bollen
}

Juli 2006

\section{Samenvatting}

Investeren in employability wordt veelal gezien als een gedeelde verantwoordelijkheid tussen werknemer en werkgever. In de praktijk blijken echter lang niet alle werknemers en werkgevers deze verantwoordelijkheid op te nemen. De Vlaamse overheid introduceerde een 'recht op externe loopbaanbegeleiding' om de tekorten in employability-investeringen bij te sturen. In dit artikel onderzoeken we of dit recht deze functie kan vervullen. We gaan tevens na hoe employability-investeringen van werkgevers en werknemers samengaan. Hiertoe voeren we een padanalyse uit met data van 803 Vlaamse werknemers. Uit de resultaten blijkt dat employability-initiatief door werkgevers werknemers ertoe aanzet zelf initiatief te nemen, dat vooral proactieve werknemers aan externe loopbaanbegeleiding willen deelnemen en dat externe loopbaanbegeleiding niet als volwaardig vangnet kan fungeren voor wie weinig employability-steun van de werkgever krijgt. 


\section{Inleiding}

Een centrale assumptie in de hedendaagse loopbaanliteratuur is dat individuen hun werkzekerheid niet langer ontlenen aan hun werkgever, maar aan de eigen employability (Boom \& Metselaar, 2001). Employability verwijst naar de duurzame inzetbaarheid op de arbeidsmarkt, ofwel iemands vermogen om werk te behouden of te verkrijgen (Delsen, 1998). DeFillippi en Arthur (1994) onderscheiden drie competenties die deze employability kunnen beïnvloeden: (1) de vaardigheden, kennis en expertise (knowing how), (2) de sterkte van het eigen sociaal netwerk (knowing whom) en (3) de duidelijkheid van de loopbaanverwachtingen (knowing why). Employability wordt daarnaast beïnvloed door de arbeidsmarktcontext (Forrier, 2003). Zo hangt de waarde van een competentie af van de vraag ernaar op de arbeidsmarkt. Bovendien kunnen kennis en vaardigheden bij onvoldoende gebruik vervagen of door wijziging in de arbeidsmarktcondities verouderen (Delsen, 1998). Daarom is het van belang voortdurend in employability te investeren.

Werknemer en werkgever worden veelal beschouwd als de primaire verantwoordelijken voor employability-investeringen (Boom \& Metselaar, 2001). Van werknemers wordt verwacht dat ze hun loopbaan in eigen handen nemen en actief mogelijkheden zoeken om de eigen employability te verruimen (Bollérot, 2001; Stickland, 1996). De activiteiten die een individu zelf initieert om de employability te onderhouden, worden gebundeld onder individueel loopbaanmanagement (ILM). Onderzoek toont aan dat individueel loopbaanmanagement zowel gericht kan zijn op de interne (ILM-intern) als op de externe employability (ILMextern) (Sturges, Guest, Conway \& Mackenzie, 2002). Met interne employability doelen we op het vermogen van het individu om tewerkgesteld te blijven bij de huidige werkgever (Sanders \& de Grip, 2004). Hierin kan geïnvesteerd worden door de eigen prestaties 'zichtbaar' te maken in het bedrijf en door bedrijfsrelevante (bedrijfsspecifieke én algemene) kennis en relaties op te bouwen (Sturges et al., 2002). Externe employability verwijst naar iemands vermogen om een baan te vinden bij een andere werkgever (Sanders \& de Grip, 2004). Voor het vrijwaren van de externe employability is een gerichtheid op de externe arbeidsmarkt belangrijk (Sturges et al., 2002). Investeringen in de interne en de externe inzetbaarheid sluiten elkaar niet uit. Bepaalde investeringen in de interne inzetbaarheid (e.g. netwerken) kunnen bovendien de externe inzetbaarheid bevorderen en omgekeerd. Wel gaat het om twee duidelijk verschillende vormen van individueel loopbaanmanagement, die elk 
een heel andere relatie hebben met bijvoorbeeld betrokkenheid bij de organisatie (Sturges, Conway, Guest \& Liefooghe, 2003; Sturges, Conway, Guest \& Liefooghe, 2005).

De verantwoordelijkheid van werkgevers bestaat erin om werknemers mogelijkheden en instrumenten te bieden om de employability te vergroten en hen te stimuleren tot eigen initiatief (Bollérot, 2001; Stickland, 1996). Het geheel van employability-investeringen die de werkgever initieert, duiden we aan met loopbaanmanagement door de organisatie (OLM). Loopbaanmanagement door de organisatie is meestal primair gericht op de bedrijfsinterne inzetbaarheid. Bij investeringen in niet-bedrijfsspecifieke competenties kan ook de externe inzetbaarheid toenemen (Gaspersz \& Ott, 1996).

Worden employability-investeringen volledig overgelaten aan het initiatief van werknemers en werkgevers, dan kunnen zich enkele problemen stellen. Ten eerste investeren niet alle werknemers in dezelfde mate in employability. Ouderen, laaggeschoolden, werknemers die zich 'werkzeker' wanen en werknemers in lagere posities scoren beduidend lager op individueel loopbaanmanagement (de Feyter, Smulders \& Vroome, 2001; Verbruggen, Forrier, Sels \& Vandenbrande, 2005). Ten tweede is de kans op loopbaanmanagement door de organisatie erg ongelijk verdeeld. Zo worden de loopbanen van laaggeschoolden, ouderen, flexibele werknemers en werknemers in kleinere bedrijven beduidend minder door werkgevers gemanaged (de Feyter et al., 2001; Forrier, 2003; Verbruggen et al., 2005). Ten derde bestaat het risico dat loopbaanmanagement door de organisatie uitsluitend gericht is op bedrijfsinterne inzetbaarheid. Bij investeringen in algemene competenties lopen werkgevers immers het risico dat hun werknemers aantrekkelijker worden voor andere werkgevers en de onderneming verlaten, wat hen zou kunnen weerhouden van zulke investeringen (Delsen, 1998). Ten vierde zouden ook werknemers zich, onder invloed van loopbaanmanagement door de organisatie, eenzijdig kunnen richten op hun interne inzetbaarheid. Hoewel employability-investeringen vrijwillig verloop in de hand kunnen werken - werknemers worden er immers meer inzetbaar door - gebeurt volgens Gaspersz en Ott (1996) net het omgekeerde. Door dergelijke investeringen profileren organisaties zich immers als 'uitstekende werkgever', wat werknemers net aan de organisatie bindt. Gaspersz en Ott (1996) duiden dit fenomeen aan met de term 'employability paradox'. 'Gebonden' werknemers zijn wellicht minder gericht op de externe arbeidsmarkt. Hierdoor kan de afhankelijkheid van de werkgever en de kwetsbaarheid bij (nakend) ontslag vergroten. 
Deze risico's kunnen als potentiële vormen van 'marktfalen' gezien worden. Het behoort tot de taak van 'externe actoren', zoals de overheid of sectororganisaties, om dit falen te corrigeren, dit met het oog op een hogere arbeidsmarktefficiëntie en meer sociale gelijkheid (OECD, 2004; Watts, 2000). In Vlaanderen introduceerde de overheid in dit kader enkele rechten op werknemersniveau. Zo is er het recht op opleidingscheques dat de kosten van zelfgeïnitieerde opleiding reduceert, het recht op betaald educatief verlof dat werknemers de mogelijkheid geeft verlof voor opleiding op te nemen met behoud van loon, het recht op tijdskrediet dat werknemers de kans geeft arbeidstijd te reduceren ten voordele van bijvoorbeeld opleidingstijd.

De meeste van deze rechten richten zich op het verruimen van 'knowing how'. 'Knowing why' en 'knowing whom' krijgen veel minder aandacht. Recent werd een recht ingevoerd dat dit hiaat probeert te dichten: het recht op externe loopbaanbegeleiding. Dit recht geeft iedere werkende Vlaming met minstens één jaar werkervaring de mogelijkheid om tegen lage kostprijs deel te nemen aan externe loopbaanbegeleiding. Het gaat om loopbaanbegeleiding die niet georganiseerd wordt op initiatief van de werkgever en waarbij de begeleider niet tewerkgesteld is door de werkgever. Externe loopbaanbegeleiding kan helpen het inzicht in de eigen competenties te verhogen, maar ook de loopbaanverwachtingen helder te stellen (knowing why) en mensen met de juiste netwerken in contact te brengen (knowing whom).

Het recht op externe loopbaanbegeleiding zou elk van de drie 'falingen' op het vlak van loopbaanmanagement kunnen aanpakken. Externe loopbaanbegeleiding kan ten eerste individuen stimuleren tot meer individueel loopbaanmanagement door hen bewust te maken van het belang ervan en hen cruciale loopbaancompetenties te leren (King, 2001; Watts, 2000). Verder kunnen werknemers die bij loopbaanmanagement door de organisatie uit de boot vallen, via het recht de loopbaansteun krijgen die ze nodig hebben. Tot slot kan externe loopbaanbegeleiding de aandacht voor externe inzetbaarheid bevorderen door een ruime variëteit aan loopbaanopties te bestuderen (Killeen, White \& Watts, 1992). Het recht op externe loopbaanbegeleiding zal deze functies echter maar kunnen vervullen als het ook werknemers bereikt die weinig individueel loopbaanmanagement vertonen, weinig loopbaansteun van de werkgever krijgen en hun externe inzetbaarheid verwaarlozen. In deze bijdrage willen we onderzoeken of dit het geval is. Bovendien willen we nagaan of de vierde potentiële marktfaling ('loopbaanmanagement door de organisatie creëert een eenzijdige 
gerichtheid op de interne inzetbaarheid') opgaat. We richten ons op volgende onderzoeksvragen:

- Heeft loopbaanmanagement door de organisatie een ander effect op intern dan op extern individueel loopbaanmanagement?

- Kan externe loopbaanbegeleiding een gebrek aan individueel loopbaanmanagement en een eenzijdige gerichtheid op de interne inzetbaarheid compenseren? Met andere woorden: tonen werknemers die weinig aan individueel loopbaanmanagement doen en werknemers die hun loopbaaninspanningen beperken tot hun interne inzetbaarheid méér interesse in externe loopbaanbegeleiding?

- Zijn loopbaanmanagement door de organisatie en externe loopbaanbegeleiding substituten of complementen? Inzicht in de samenhang tussen loopbaanmanagement door de organisatie en externe loopbaanbegeleiding laat toe om na te gaan of externe loopbaanbegeleiding als vangnet kan fungeren voor werknemers die in hun organisatie weinig loopbaansteun krijgen. Deze vraag is tevens belangrijk vanuit efficiëntieoverwegingen. Investeren in externe loopbaanbegeleiding is weinig doelmatig als het een substituut vormt voor loopbaanmanagement door de werkgever.

We bouwen eerst een onderzoeksmodel op. Daarna zetten we de gebruikte methodologie uiteen. Tot slot worden de resultaten besproken en bediscussieerd.

\section{Hypothesen}

Figuur 1 geeft het onderzoeksmodel dat we zullen testen. Naast de centrale variabelen (OLM, ILM-intern, ILM-extern en de deelname-intentie aan externe loopbaanbegeleiding) hebben we ook loopbaantevredenheid opgenomen in het model. Er zijn immers sterke aanwijzingen dat loopbaantevredenheid een belangrijke rol speelt in het loopbaanmanagementproces. Zowel in loopbaantheorieën als in empirisch loopbaanonderzoek werd loopbaantevredenheid veelvuldig - en meer dan andere variabelen - gelinkt aan elk van de centrale variabelen (e.g. Brown, 2001; Dawis \& Lofquist, 1984; Griffeth, Gaertner \& Sager, 1999; Griffin \& Hesketh, 2003; Killeen \& White, 2000; Orpen, 1994; Raabe \& Beehr, 2005).

Hieronder lichten we elke relatie uit het model toe. We volgen daarbij de nummering zoals aangegeven in figuur 1 . 


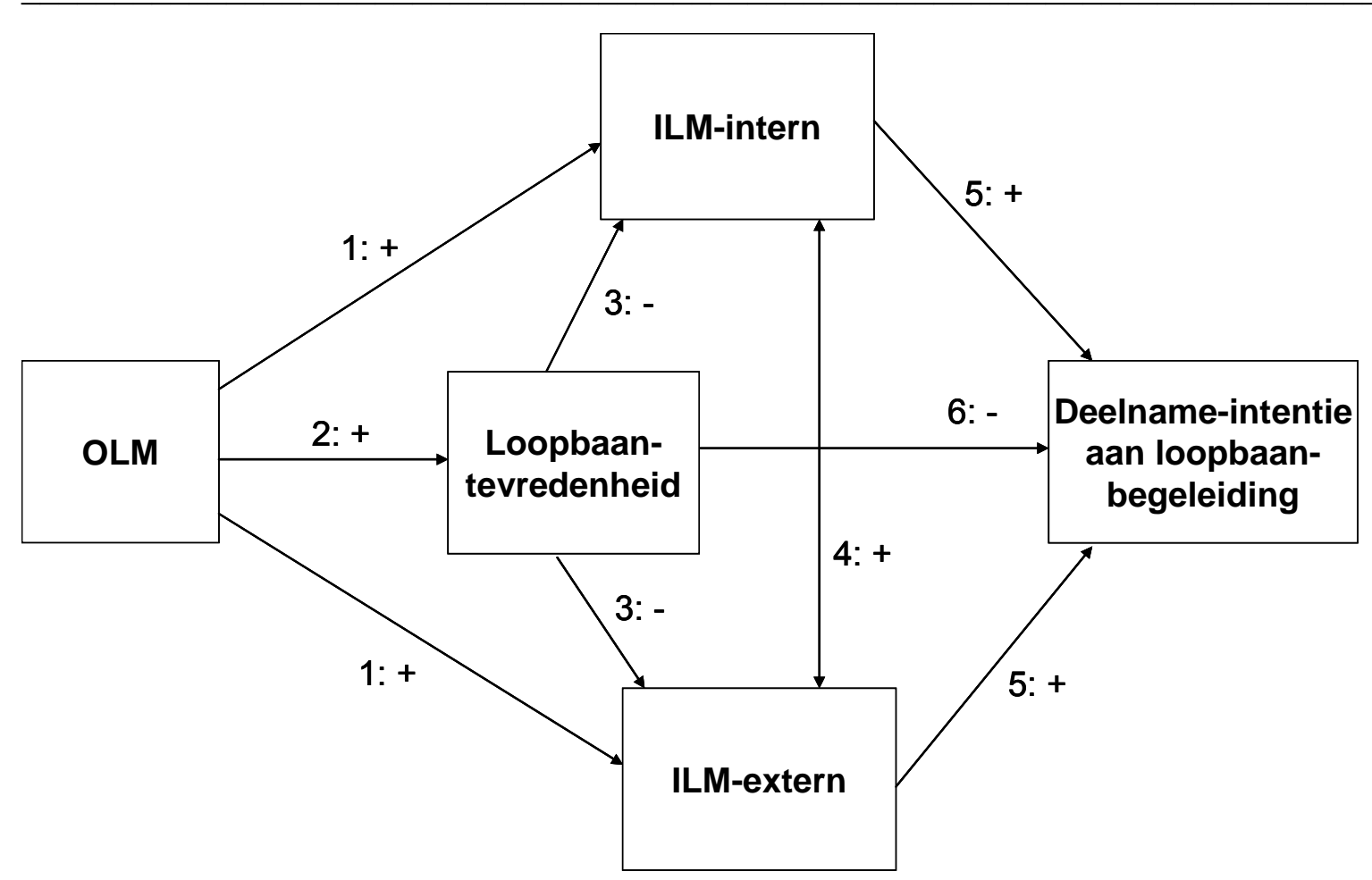

Figuur 1: Het onderzoeksmodel

\section{Relatie 1: OLM - ILM}

Van Dam (2004) vond dat bepaalde loopbaanmanagementactiviteiten door de organisatie aanzetten tot individueel loopbaanmanagement. Loopbaanmanagement door de organisatie, maakt werknemers vermoedelijk meer bewust van het belang en de voordelen van loopbaanmanagement, wat hen ertoe kan aanzetten ook zelf meer aan loopbaanmanagement te doen. Loopbaanmanagement door de organisatie kan ook het zelfinzicht en de kennis van loopbaanalternatieven vergroten (Kidd, Jackson \& Hirsch, 2003). Onderzoek suggereert dat net van deze kennis een positief effect uitgaat op individueel loopbaanmanagement (Anakwe, Hall \& Schor, 2000).

Loopbaanmanagement door de organisatie kan ook inwerken op het zelfvertrouwen en zo individueel loopbaanmanagement bevorderen. Loopbaanmanagement door de organisatie vraagt veelal een actieve houding van de werknemer. Als een organisatie een werknemer de kans geeft opleiding te volgen, dan is het aan de werknemer om die kans te grijpen en als leerervaring te benutten. Of wanneer beslist wordt een loopbaanplan op te stellen, dan wordt verwacht dat de werknemer mee de doelen en stappen bepaalt. Het (gedeeltelijk) zelf uitvoeren van loopbaanmanagementactiviteiten kan het zelfvertrouwen voor die activiteiten 
vergroten, wat op zijn beurt individueel loopbaanmanagement kan aanscherpen (Bandura, 1986; King, 2004).

Hypothese 1: Loopbaanmanagement door de organisatie zet aan tot individueel loopbaanmanagement.

We vermoeden dat loopbaanmanagement door de organisatie een sterker effect heeft op intern dan op extern individueel loopbaanmanagement. Werknemers die van hun organisatie employability-steun krijgen, voelen zich meer betrokken bij hun organisatie (Kidd et al., 2003; Sturges et al., 2003). Gebonden werknemers richten hun individueel loopbaanmanagement wellicht vooral op de inzetbaarheid in de organisatie. Ook de sociale uitwisselingstheorie laat vermoeden dat het effect van loopbaanmanagement door de organisatie sterker is voor intern dan voor extern individueel loopbaanmanagement. Deze theorie suggereert dat werknemers die steun krijgen van hun werkgever, zich verplicht voelen om iets terug te doen (Eisenberger, Huntington, Hutchison \& Sowa, 1986). Werknemers die employability-steun krijgen van hun werkgever, kunnen zich bijgevolg moreel verplicht voelen hun individueel loopbaanmanagement te focussen op de interne inzetbaarheid (Sturges et al., 2003). Dit levert de werkgever immers meer rechtstreeks voordeel op dan extern individueel loopbaanmanagement.

Hypothese 2: Loopbaanmanagement door de organisatie heeft een sterker effect op intern dan op extern individueel loopbaanmanagement.

\section{Relatie 2: OLM - Loopbaantevredenheid}

Eerder onderzoek vond positieve verbanden tussen loopbaanmanagement door de organisatie en loopbaantevredenheid. Dit geldt zowel voor specifieke loopbaanmanagementactiviteiten, zoals het toekennen van een mentor (Joiner, Bartram \& Garreffa, 2004), als voor loopbaanmanagement in het algemeen (Orpen, 1994). Een onderneming die aan loopbaanmanagement doet, zendt het signaal uit dat ze de werknemers waardeert en belang hecht aan hun loopbaanontwikkeling. Werknemers blijken dit vaak ook zo te ervaren (Kraimer, Seibert, Wayne \& Liden, 2003), wat kan leiden tot een grotere tevredenheid met de arbeidssituatie (Rhoades \& Eisenberger, 2002).

Via loopbaanmanagement kan de organisatie bovendien de kloof tussen de nagestreefde en de werkelijke loopbaan van de werknemer dichten (Jiang \& Klein, 2002; Van Maanen \& Schein, 
1979). Zo kan een loopbaangesprek inzicht geven in de verwachtingen en ambities van de werknemer en kan een loopbaanplan die werknemer wijzen op de stappen nodig om de gewenste loopbaan te realiseren. Loopbaanmanagement door de organisatie kan een werknemer bijgevolg helpen om binnen het bedrijf een loopbaan te ontwikkelen die afgestemd is op de persoonlijke verwachtingen. Deze afstemming kan de loopbaantevredenheid verhogen (Jiang \& Klein, 2002).

Hypothese 3: Loopbaanmanagement door de organisatie heeft een positieve invloed op loopbaantevredenheid.

\section{Relatie 3: Loopbaantevredenheid - ILM}

De 'werkaanpassings'-theorie van Dawis en Lofquist (1984) stelt dat ontevredenheid met de loopbaan een belangrijke prikkel is om employability-initiatief te nemen. Ook Crites (1969) veronderstelt dat frustratie over de werksituatie, bijvoorbeeld geuit in ontevredenheid met de loopbaan, een stimulus kan zijn om zelf actie te ondernemen (King, 2004). Deze theoretische link tussen ontevredenheid en loopbaanacties werd tevens teruggevonden in verschillende empirische studies (e.g. Bretz, Boudreau \& Judge, 1994; Griffin \& Hesketh, 2003; Rosse \& Hulin, 1985; Van Hooft, Born, Taris, Van Der Flier \& Blonk, 2004). We merken op dat loopbaanontevredenheid ook kan leiden tot meer passieve reacties, zoals aanvaarding van de situatie of verzuim (Griffeth, Gaertner \& Sager, 1999). In deze studie ligt de focus op de actieve reacties. In lijn met de aangehaalde theorieën en empirische studies, verwachten we dat loopbaanontevredenheid individueel loopbaanmanagement stimuleert; of omgekeerd: dat tevredenheid individueel loopbaanmanagement afremt.

Hypothese 4: Loopbaantevredenheid heeft een negatieve invloed op individueel loopbaanmanagement.

We verwachten dus een negatieve invloed op zowel intern als extern individueel loopbaanmanagement. Een impact op intern individueel loopbaanmanagement kan verwacht worden als de werknemer een verdere loopbaan in de huidige organisatie aspireert. Stel dat de loopbaan zich niet naar wens ontwikkelt omdat de werknemer te weinig opvalt en daardoor promoties misloopt, omdat de hiërarchie niet op de hoogte is van de loopbaanwensen of omdat de werknemer geen duidelijke feedback krijgt over prestaties en bijgevolg niet weet in welke richting te evolueren. In al deze gevallen kan loopbaanmanagement gericht op de interne loopbaan uitkomst bieden. In de 
loopbaanliteratuur wordt ontevredenheid echter in hoofdzaak in verband gebracht met investeringen in de externe inzetbaarheid (e.g. Bretz et al., 1994; Van Hooft et al., 2004). We vermoeden daarom dat werknemers die ontevreden zijn met hun loopbaan, vaker extern individueel loopbaanmanagement zullen ondernemen. Dit zal wellicht het geval zijn als de gewenste loopbaan niet in de huidige onderneming te realiseren is of als de ontevredenheid met de loopbaan veroorzaakt wordt door of omslaat in ontevredenheid met de organisatie of het loopbaanbeleid.

Hypothese 5: Loopbaantevredenheid heeft een sterker effect op extern dan op intern individueel loopbaanmanagement.

\section{Relatie 4: ILM-intern - ILM-extern}

We vermoeden dat intern en extern individueel loopbaanmanagement positief gerelateerd zijn. Beide kunnen beschouwd worden als vormen van proactief gedrag, namelijk 'het nemen van initiatief om de huidige situatie te verbeteren of te veranderen en het uitdagen van de status quo, eerder dan zich passief aan te passen aan de omstandigheden' (Crants, 2000). Volgens Seibert, Kraimer en Crant (2001) zijn verschillende vormen van proactief gedrag positief gecorreleerd omdat ze veroorzaakt worden door dezelfde persoonlijkheidstrek, namelijk 'proactiviteit'. Ook ander onderzoek suggereert dat persoonlijkheid gelinkt is aan individueel loopbaanmanagement. Zo werden verbanden vastgesteld tussen employabilityinvesteringen en ambitie (Guthrie, Coate \& Schwoerer, 1998) en openheid voor ervaring (Guthrie et al., 1998; Van Dam, 2004).

Hypothese 6: Extern individueel loopbaanmanagement en intern individueel loopbaanmanagement zijn positief gecorreleerd.

\section{Relatie 5: ILM - Deelname-intentie aan externe loopbaanbegeleiding}

We vermoeden dat individueel loopbaanmanagement positief inwerkt op de intentie om aan externe loopbaanbegeleiding deel te nemen. Van der Heijden (2002) stelt dat het ondernemen van individueel loopbaanmanagement getuigt van loopbaaninitiatief. Individuen met een hoge graad van loopbaaninitiatief zouden persoonlijke voordelen zien in deelname aan dergelijke activiteiten. Onderzoek toont bovendien aan dat wie de voordelen inziet van een employability-activiteit, een hogere intentie vertoont om aan die activiteit deel te nemen (Maurer \& Tarulli, 1994; Van Hooft et al., 2004). 
Hypothese 7: Individueel loopbaanmanagement heeft een positief effect op de deelname-intentie aan externe loopbaanbegeleiding.

We verwachten tevens dat extern individueel loopbaanmanagement een sterker effect heeft op de deelname-intentie aan externe loopbaanbegeleiding dan intern individueel loopbaanmanagement. Tijdens externe loopbaanbegeleiding wordt stilgestaan bij de waarde van iemands competenties voor de ruimere arbeidsmarkt en worden ook loopbaanalternatieven buiten de huidige organisatie bekeken. Deze expliciete aandacht voor de externe inzetbaarheid komt overeen met de focus in extern individueel loopbaanmanagement.

Hypothese 8: Extern individueel loopbaanmanagement heeft een sterkere invloed op de deelname-intentie aan externe loopbaanbegeleiding dan intern individueel loopbaanmanagement.

\section{Relatie 6: Loopbaantevredenheid - Deelname-intentie aan loopbaanbegeleiding}

We verwachten dat werknemers die ontevreden zijn met hun loopbaan meer voordeel zien in externe loopbaanbegeleiding en daarom een hogere intentie zullen vertonen om eraan deel te nemen. Externe loopbaanbegeleiding houdt immers impliciet de belofte in dat naar een uitweg zal worden gezocht en belooft een nieuwe uitdaging op professioneel gebied. Eerder onderzoek heeft bovendien aangewezen dat werknemers die de stap naar externe loopbaanbegeleiding zetten dit veelal doen uit ontevredenheid met hun loopbaan (Brown, 2001; Killeen \& White, 2000).

Hypothese 9: Loopbaantevredenheid heeft een negatieve invloed op de deelnameintentie aan externe loopbaanbegeleiding

\section{Methode}

\section{Data}

Om onze hypothesen te testen, maken we gebruik van de data die werden verzameld in het kader van het Viona-project 'Draagvlak voor een recht op loopbaanbegeleiding' (Verbruggen et al., 2005). Deze studie ging na in welke mate Vlaamse werknemers nood hebben aan externe loopbaanbegeleiding en in welke mate zij van plan zijn er beroep op te doen. Daartoe werd in 2004 een survey uitgevoerd bij een representatieve steekproef van Vlaamse 
werknemers. De steekproef was proportioneel gestratificeerd op basis van twee stratificatievariabelen: leeftijd en opleidingsniveau. Deze variabelen werden gekozen omdat ze een invloed hebben op loopbaanuitkomsten, zoals loopbaantevredenheid en het ondernemen van loopbaanstrategieën (Guthrie et al., 1998; Tharenou, 1997), en bijgevolg ook de deelname-intentie aan externe loopbaanbegeleiding kunnen beïnvloeden.

De data werden verzameld aan de hand van een gestandaardiseerde vragenlijst. De respondenten werden geïnterviewd door 65 professionele interviewers (random walk methode) (Kooiker, 2003). Uiteindelijk werden 957 bruikbare interviews afgenomen. De proporties naar leeftijd en opleidingsniveau in de steekproef weerspiegelen de proporties in de Vlaamse populatie (Steunpunt WAV, 2005). De steekproef bevat ongeveer evenveel mannen $(50,2 \%)$ als vrouwen $(49,8 \%)$.

\section{Variabelen}

Loopbaanmanagement door de organisatie werd gemeten met 10 items van Sturges et al. (2002). De respondenten moesten voor iedere stelling aangeven in welke mate ze akkoord gingen (1: helemaal niet akkoord - 5: helemaal akkoord). Twee voorbeelditems zijn: 'Mijn baas zorgt ervoor dat ik de opleiding krijg die ik nodig heb voor mijn loopbaan' en 'Ik heb een mentor gekregen die me helpt bij de ontwikkeling van mijn loopbaan'. Factoranalyse volgens de principale componentenanalyse wees op 2 factoren met een eigenwaarde groter dan 1. De screeplot toonde echter aan dat 1 factor volstond. Een betrouwbaarheidsanalyse wees op een goede interne consistentie van deze factor $(\alpha=0,91)$.

Individueel loopbaanmanagement werd eveneens gemeten met een schaal van Sturges et al. (2002). De respondenten moesten 16 items beoordelen op een 5-puntenschaal (1: helemaal niet akkoord - 5: helemaal akkoord). 8 items peilden naar activiteiten gericht op interne inzetbaarheid (ILM-intern) en 8 naar activiteiten gericht op externe inzetbaarheid (ILMextern). Twee voorbeelditems van intern individueel loopbaanmanagement zijn: 'Ik heb veel contacten met belangrijke personen in mijn organisatie' en 'Ik zorg ervoor dat ik erkenning krijg voor het werk dat ik doe'. Twee voorbeelditems van extern individueel loopbaanmanagement zijn: 'Ik hou mijn CV up-to-date' en 'Ik bekijk jobadvertenties om te zien welke banen er buiten deze organisatie beschikbaar zijn'. Een factoranalyse volgens de principale componentenanalyse wees op 2 factoren die na varimaxrotatie duidelijk interpreteerbaar waren als ILM-intern $\left(\alpha_{\text {ILM-intern }}=0,84\right)$ en ILM-extern $\left(\alpha_{\text {ILM-extern }}=0,85\right)$. 
Loopbaantevredenheid werd gemeten met 3 stellingen van Martins, Eddleston en Veiga (2002). De respondenten dienden op een 7-puntenschaal (1: helemaal niet akkoord-7: helemaal akkoord) aan te duiden hoe tevreden ze waren met hun loopbaan, met de huidige baan en met de vooruitgang die ze tot nu toe gemaakt hadden in de loopbaan. De drie items bleken tot eenzelfde schaal te behoorden $(\alpha=0,84)$.

De scores op de vier bovenvermelde schalen (loopbaanmanagement door de organisatie, intern en extern individueel loopbaanmanagement en loopbaantevredenheid) werden omgezet naar een somscore op 10, waarbij een hogere score wijst op een sterkere aanwezigheid van de respectievelijke elementen. We verkozen somscores boven factorscores omdat factorladingen vaak erg afhankelijk zijn van de gebruikte dataset (Hair, Anderson \& Tatham, 1995). We opteerden daarbij voor omzetting naar een punt op 10 eerder dan voor een somscore op de oorspronkelijke schaal (5-punten of 7-punten) omdat een punt op 10 erg eenvoudig te interpreteren is. Deze keuze heeft geen invloed op de analyseresultaten.

Deelname-intentie aan externe loopbaanbegeleiding werd gemeten door respondenten te laten inschatten hoe groot de kans is dat ze binnen 5 jaar zouden deelnemen aan externe loopbaanbegeleiding als de overheid de kosten volledig zou dekken. Respondenten konden antwoorden op een 4-puntenschaal gaande van 1: 'die kans is onbestaande' tot 4: 'die kans is zeer groot'. We voegden ook een 'weet niet'-antwoordcategorie toe die de respondenten toeliet te antwoorden: 'dat kan ik momenteel onmogelijk inschatten'. Die groep respondenten $(n=124)$ is niet meegenomen in de verdere analyses. Om controle te houden over de interpretatie van 'externe loopbaanbegeleiding' werd dit begrip verduidelijkt met een gestandaardiseerde omschrijving (zie Tabel 1).

Controlevariabelen. We controleren voor geslacht, leeftijd (20-34; 35-44; 45-64 jaar), opleidingsniveau (laag-; midden-; hooggeschoold), contractvorm (vast; flexibel) en organisatiegrootte $(1-9 ; 10-49 ; 50-99 ; 100-499 ; 500+$ werknemers $)$. Alle controlevariabelen werden in de analyses opgenomen als dummies. 
Tabel 1: Gestandaardiseerde omschrijving van het begrip "Loopbaanbegeleiding"

\section{Wat wij in dit onderzoek onder loopbaanbegeleiding verstaan:}

Loopbaanbegeleiding begeleidt en adviseert mensen die keuzes willen maken in hun loopbaan en helpt hen een antwoord te zoeken op vragen als:

- Ik doe al jaren hetzelfde werk. Ik wil nu graag iets anders. Hoe begin ik hieraan? Welke jobs zijn er voor mij beschikbaar?

- $\quad$ Ik voel me niet gelukkig in mijn job. Wat is het probleem en wat kan ik eraan doen?

- Ik zit aan het einde van mijn loopbaan. Werken begint teveel voor me te worden. Maar ik heb het geld nodig. Hoe kan ik nog verder?

- Hoe stem ik mijn werk en de rest van mijn leven beter op elkaar af?

- $\quad$ Ik wil graag als zelfstandige beginnen. Hoe pak ik dit aan? Wat zal er allemaal veranderen?

- $\quad$ Ik wil graag even stilstaan bij mijn loopbaan. Past mijn huidige job wel bij me? Welke mogelijkheden biedt mijn huidige werkgever me? Is het dat wat ik wil?

Loopbaanbegeleiding bestaat uit een aantal gesprekken, individueel of in groep, met een professionele begeleider. Het traject eindigt met een concreet actieplan. Hierin wordt stap voor stap overlopen welke acties je kan ondernemen om je doel te bereiken en hoe eventuele hindernissen kunnen worden overwonnen. Je gegevens worden steeds strikt vertrouwelijk behandeld.

Sommige ondernemingen bieden aan hun werknemers de mogelijkheid om loopbaanbegeleiding te volgen. Maar je kan ook onafhankelijk van je werkgever beslissen om aan loopbaanbegeleiding deel te nemen. Je werkgever hoeft hier niet van op de hoogte te zijn. Je kan hiervoor terecht bij gespecialiseerde loopbaancentra.

\section{Analyses}

Het model werd getest met padanalyse (procedure CALIS in SAS) (Hatcher, 1998). Deze techniek laat toe alle relaties gelijktijdig te testen. De analyse wijst op een goede fit tussen het vooropgestelde model en de geobserveerde data. Alle fit-indicatoren overschrijden de aanbevolen minimumwaarden $\left(\chi^{2}=0,0444\right.$ met $\mathrm{df}=1$ en $\mathrm{p}$-waarde $=0,833 ; \mathrm{GFI}=1,000$; AGFI=0,999; CFI=1,000; NFI=1,000; NNFI=1,053). De modificatie-indices wijzen wel aan dat de pijl tussen intern individueel loopbaanmanagement en de deelname-intentie aan externe loopbaanbegeleiding weggelaten kan worden zonder de fit van het model te verslechteren.

\section{Resultaten}

Tabel 2 bevat de gemiddelden, standaarddeviaties en correlaties van de verschillende variabelen. Opvallend zijn de lage scores op de loopbaanmanagementschalen. Vooral de gemiddelde score op extern individueel loopbaanmanagement is laag. De gemiddelde Vlaamse werknemer investeert blijkbaar nauwelijks in externe inzetbaarheid. Maar ook intern individueel loopbaanmanagement en loopbaanmanagement door de organisatie scoren relatief laag. Verder blijkt de gemiddelde Vlaamse werknemer vrij tevreden met zijn loopbaan 
(gemiddelde: 7,4/10) en vertoont hij een zekere intentie om in de nabije toekomst aan externe loopbaanbegeleiding deel te nemen. Tabel 2 wijst op sterke correlaties tussen de variabelen. Enkel loopbaanmanagement door de organisatie en deelname-intentie aan externe loopbaanbegeleiding blijken niet significant gecorreleerd.

Tabel 2: Aantallen (n), gemiddelden (m), standaarddeviaties (sd) en correlaties

\begin{tabular}{|c|c|c|c|c|c|c|c|}
\hline & $\mathrm{n}$ & $m^{1}$ & $\mathrm{sd}$ & 1 & 2 & 3 & 4 \\
\hline 1. $\mathrm{OLM}^{2}$ & 952 & 4,05 & 2,40 & - & & & \\
\hline Loopbaantevredenheid & 956 & 7,37 & 2,26 &, $431^{* * *}$ & - & & \\
\hline ILM-intern & 953 & 4,67 & 2,21 &, $536^{\star * *}$ &, $214^{* * *}$ & - & \\
\hline 4. ILM-extern & 953 & 2,86 & 2,25 & $124^{* * *}$ &,$- 183^{* * *}$ &, $470 * * *$ & - \\
\hline $\begin{array}{l}\text { 5. Deelname-intentie aan externe } \\
\text { loopbaanbegeleiding }\end{array}$ & 833 & 2,66 & 0,93 &,- 009 &,$- 208^{* * *}$ & $122^{* * *}$ &, $348^{* * *}$ \\
\hline
\end{tabular}

$* * * \mathrm{p}<0,001 ; * * \mathrm{p}<0,01 ;{ }^{*} \mathrm{p}<0,05$

${ }^{1}$ De gemiddelden voor OLM, loopbaantevredenheid, ILM-intern en ILM-extern worden gegeven met een cijfer tussen 0 en 10. De deelname-intentie aan externe loopbaanbegeleiding werd gemeten met een 4-puntenschaal gaande van 1 tot 4 .

2 OLM staat voor Loopbaanmanagement door de organisatie, ILM-intern voor intern individueel loopbaanmanagement en ILM-extern voor extern individueel loopbaanmanagement

Figuur 2 geeft de resultaten van de padanalyse.

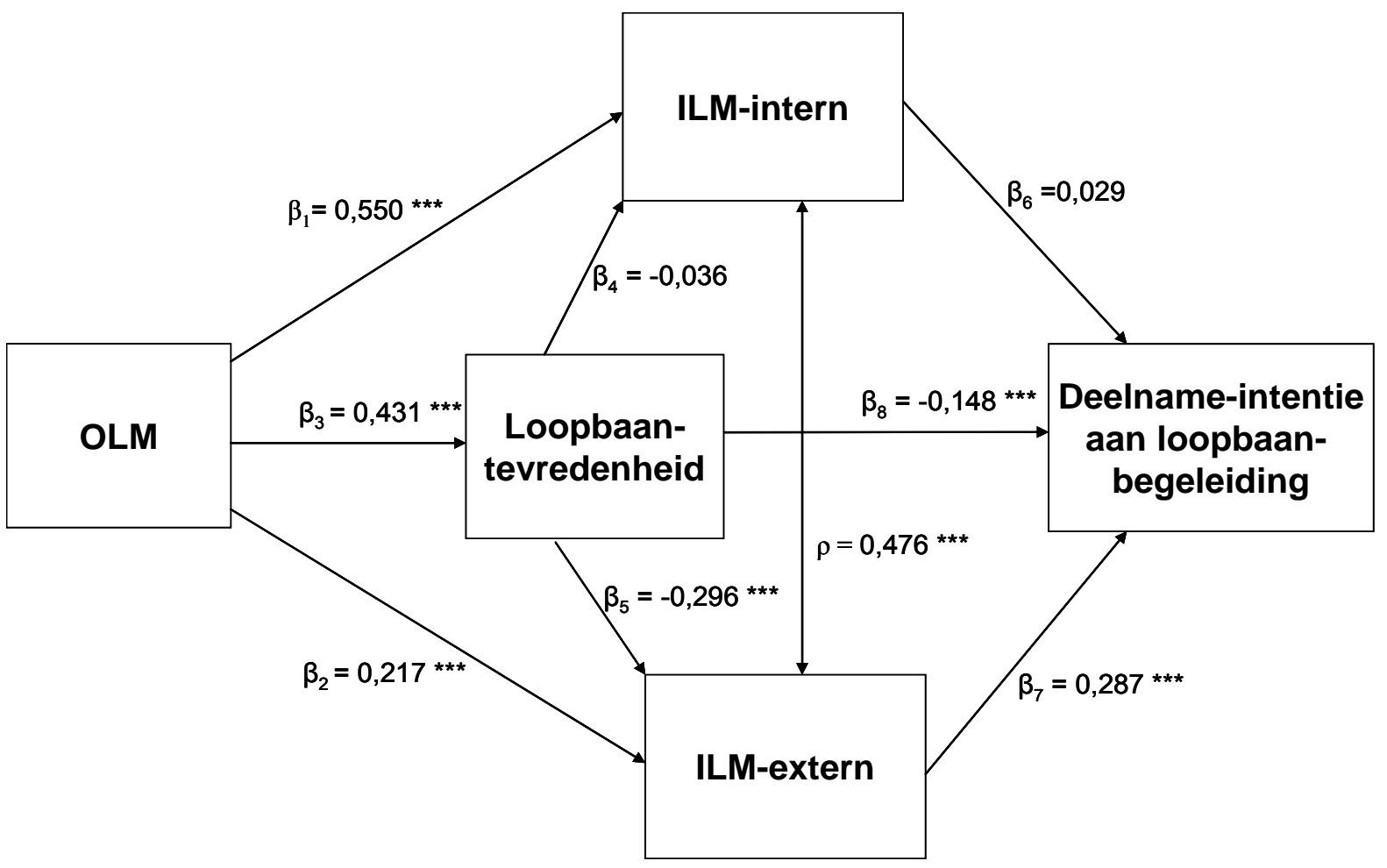

Figuur 2: Gestandaardiseerde padcoëfficiënten $(n=803)$

Hypothesen 1 en 2 over de rechtstreekse relatie tussen loopbaanmanagement door de werkgever en individueel loopbaanmanagement worden bevestigd. Niet alleen heeft loopbaanmanagement door de organisatie een positieve invloed op beide ILM-variabelen 
(hypothese 1), zoals verwacht is de invloed sterker voor intern dan voor extern individueel loopbaanmanagement (hypothese 2). Het verschil in effect is bovendien significant, aangezien er geen overlap is tussen de 95\%-betrouwbaarheidsintervallen van $\beta_{1}$ en $\beta_{2}$.

We bekijken vervolgens de relatie tussen loopbaanmanagement door de organisatie en individueel loopbaanmanagement via loopbaantevredenheid. Van loopbaanmanagement door de organisatie gaat een significant positief effect uit op loopbaantevredenheid, zodat we hypothese 3 kunnen aanvaarden. Loopbaantevredenheid blijkt op haar beurt individueel loopbaanmanagement negatief te beïnvloeden. Dit effect is echter niet significant voor intern individueel loopbaanmanagement ( $\mathrm{p}$-waarde=0,261). Hypothese 4 kunnen we bijgevolg slechts gedeeltelijk aanvaarden. Hypothese 5 tenslotte, die stelt dat loopbaantevredenheid een sterker negatief effect heeft op extern dan op intern individueel loopbaanmanagement, wordt bevestigd. De 95\%-betrouwbaarheidsintervallen van $\beta_{4}$ en $\beta_{5}$ blijken immers niet te overlappen.

Tabel 3: Totale effecten (gestandaardiseerde padcoëfficiënten, $n=803$ )

\begin{tabular}{|c|c|c|c|c|}
\hline \multirow{4}{*}{ 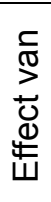 } & & \multicolumn{3}{|c|}{ Op } \\
\hline & & ILM-intern & ILM-extern & $\begin{array}{c}\text { Deelname-intentie aan externe } \\
\text { loopbaanbegeleiding }\end{array}$ \\
\hline & OLM & $0,550 * * *$ & $0,089^{* *}$ & $-0,038$ \\
\hline & Loopbaantevredenheid & - & - & $-0,233^{* * *}$ \\
\hline
\end{tabular}

$* * * \mathrm{p}<0,001 ; * * \mathrm{p}<0,01 ; * \mathrm{p}<0,05$

De significantie van de totale effecten werd bepaald volgens de methode voorgesteld door Kline (1998).

Om zicht te krijgen op het totale effect van loopbaanmanagement door de organisatie op individueel loopbaanmanagement bekijken we Tabel 3. We zien een sterk positief effect van loopbaanmanagement door de organisatie op intern individueel loopbaanmanagement. Het effect op extern individueel loopbaanmanagement is eveneens significant positief, maar beduidend minder groot.

In Figuur 2 zien we verder dat intern en extern individueel loopbaanmanagement sterk positief correleren, zodat we hypothese 6 kunnen aanvaarden. Van beide variabelen gaat bovendien een positief effect uit op de deelname-intentie aan externe loopbaanbegeleiding. Dit effect is echter enkel significant voor extern individueel loopbaanmanagement ( $p$ waarde $_{\text {ILM-intern }}=0,466$ ). Hypothese 7 wordt bijgevolg slechts gedeeltelijk bevestigd. Het effect van extern individueel loopbaanmanagement blijkt significant groter dan dat van intern individueel loopbaanmanagement (geen overlap tussen de 95\%-betrouwbaarheidsintervallen). Hypothese 8 wordt dus bevestigd. 
Figuur 2 toont verder dat het directe effect van loopbaantevredenheid op de deelname-intentie aan externe loopbaanbegeleiding significant negatief is. Hypothese 9 wordt bijgevolg bevestigd. Bovendien blijkt ook het indirecte effect via individueel loopbaanmanagement negatief, wat resulteert in een sterk negatief totaal effect (Tabel 3).

Tot slot blijkt uit Tabel 3 dat het totale effect van loopbaanmanagement door de organisatie op de deelname-intentie aan externe loopbaanbegeleiding licht negatief is. Dit effect is echter niet significant verschillend van nul.

\section{Discussie}

De resultaten suggereren dat loopbaanmanagement door de organisatie werknemers kan stimuleren om zelf aan hun interne én externe employability te werken. Loopbaanmanagement door de organisatie verdient daarom aanmoediging. Belangrijke vaststelling is dat loopbaansteun door de werkgever geen uitsluitende gerichtheid op de interne inzetbaarheid creëert. Wel blijkt het effect op intern individueel loopbaanmanagement bijna zes keer sterker dan het effect op extern individueel loopbaanmanagement. Dat is niet onlogisch; werkgevers hebben er immers meer rechtstreeks voordeel bij wanneer hun werknemers in de interne inzetbaarheid investeren. Toch kunnen werkgevers ook baat hebben bij een beroepsbevolking met een grotere externe inzetbaarheid. Individuen die beter extern inzetbaar zijn, kunnen de instroom van "fris bloed" in organisaties bevorderen, wat ervaringsconcentratie van het werknemersbestand kan voorkomen (de Grip, van Loo \& Sanders, 2004). Als werkgevers hier meer van doordrongen zouden worden, zou de kloof tussen investeringen in de interne en de externe inzetbaarheid mogelijk verkleinen.

Het positieve verband tussen loopbaanmanagement door de organisatie en individueel loopbaanmanagement hoeft echter niet te betekenen dat het eerste aanzet tot het tweede. De methode die we gebruikt hebben (padanalyse op cross-sectionele data) laat immers niet toe een uitspraak te doen over de richting van de verbanden. Het is mogelijk dat de relatie omgekeerd loopt, namelijk dat individueel loopbaanmanagement leidt tot loopbaanmanagement door de organisatie, of dat individueel loopbaanmanagement en loopbaanmanagement door de organisatie beide door een derde factor bepaald worden. Zo zouden talentvolle werknemers die veel kans maken om bij andere werkgevers aan de slag te gaan, veel in hun inzetbaarheid kunnen investeren. Dergelijke investeringen kunnen immers helpen om hun loopbaankansen te verzilveren. Mogelijk bieden ook werkgevers net aan deze 
werknemers veel loopbaanmanagementmogelijkheden aan, dit met het oog op retentiemanagement. In dat geval worden zowel individueel loopbaanmanagement als loopbaanmanagement door de organisatie beïnvloed door éénzelfde derde factor, namelijk mobiliteitskansen. Voor deze mogelijkheid werd wel enigszins gecontroleerd door het opleidingsniveau als variabele op te nemen. Verder zou het ook kunnen dat (intern) individueel loopbaanmanagement aanzet tot loopbaanmanagement door de werkgever. Werknemers die aan hun bedrijfsinterne inzetbaarheid werken (bijvoorbeeld door hun baas bewust te maken van wat ze verwezenlijkt hebben of door contacten te leggen met belangrijke mensen in de organisatie) vallen wellicht meer op en krijgen daardoor mogelijk meer loopbaansteun van de werkgever. Met onze cross-sectionele dataset kunnen we hier echter geen uitspraak over doen.

We staan vervolgens stil bij de vraag hoe werknemersinitiatief samengaat met externe loopbaanbegeleiding. Wie activiteiten onderneemt gericht op externe inzetbaarheid, vertoont een grotere bereidheid om deel te nemen aan externe loopbaanbegeleiding. Dit wijst erop dat meer proactieve werknemers, die sowieso oog hebben voor hun employability, via externe loopbaanbegeleiding hun employability nog meer willen versterken. Er kunnen echter ook andere factoren spelen. Zo is het mogelijk dat vooral werknemers die een loopbaanverandering verwachten of plannen, activiteiten ondernemen gericht op hun externe inzetbaarheid. Het lijkt niet onlogisch dat deze werknemers ook meer voordeel zien in een externe dienstverlening die hen kan helpen bij het maken van zulke transities. Om die mogelijkheid te testen herhaalden we de analyses met een extra controlevariabele, namelijk een dummy die 1 is als de persoon in de komende 5 jaar een loopbaanverandering verwacht. Het effect van extern individueel loopbaanmanagement werd hierdoor licht verminderd, maar bleef sterk én significant. Het verwachten van een transitie kan bijgevolg slechts een beperkt deel verklaren van het positieve verband tussen extern individueel loopbaanmanagement enerzijds en de deelname-intentie aan externe loopbaanbegeleiding anderzijds.

Intern individueel loopbaanmanagement bleek geen effect te hebben op de deelname-intentie aan externe loopbaanbegeleiding. Wie initiatieven onderneemt gericht op de interne inzetbaarheid is dus niet meer, maar ook niet minder, dan anderen geneigd naar externe loopbaanbegeleiding te stappen. Mogelijk associëren werknemers externe loopbaanbegeleiding enkel met externe inzetbaarheid en zien ze de dienstverlening niet als een instrument om de interne inzetbaarheid te verruimen. 
De laatste onderzoeksvraag ging over de samenhang tussen werkgeversinitiatief en externe loopbaanbegeleiding. Onze analyses wijzen op twee compenserende mechanismen. Enerzijds beïnvloedt loopbaanmanagement door de organisatie de deelname-intentie aan externe loopbaanbegeleiding negatief via loopbaantevredenheid. Werknemers die loopbaansteun krijgen van hun organisatie, zijn meer tevreden met hun loopbaan en daardoor minder gestimuleerd om in externe begeleiding te stappen. Anderzijds beïnvloedt loopbaanmanagement door de organisatie de deelname-intentie positief via extern individueel loopbaanmanagement. Loopbaanmanagement door de organisatie zet aan tot extern individueel loopbaanmanagement, dat op zijn beurt een positief effect heeft op de intentie om aan externe loopbaanbegeleiding deel te nemen. Deze twee mechanismen heffen elkaar op, met als resultaat een nuleffect van loopbaanmanagement door de organisatie op de vraag naar externe loopbaanbegeleiding.

Dit nuleffect geeft aan dat beide instrumenten in de ogen van werknemers deels een andere functie vervullen. Loopbaanmanagement door de organisatie helpt individuen vooral bij de loopbaanuitbouw binnen de organisatie. Het fungeert als een soort olie op de interne arbeidsmarkt en is vooral gericht op blijvende interne inzetbaarheid. Externe loopbaanbegeleiding gaat ruimer en stelt de huidige arbeidsmarktpositie meer fundamenteel in vraag. Voor sommige loopbaanproblemen is dat ook nodig. Wie bijvoorbeeld een andere baan wil, maar ook wie meer zelfinzicht wil verwerven of zicht wil op passende beroepen en functies, heeft er baat bij over de bedrijfsmuren te kijken. Externe begeleiding biedt werknemers deze kans. De dienstverlening helpt hen op een neutrale manier de loopbaandoelen in vraag te stellen en open te trekken. Dat loopbaanmanagement door de organisatie de deelname-intentie aan externe loopbaanbegeleiding nauwelijks beïnvloedt, impliceert echter ook dat wie van zijn werkgever geen loopbaanondersteuning krijgt, niet vaker dan anderen van plan is om zelf steun te zoeken via externe loopbaanbegeleiding. Externe loopbaanbegeleiding lijkt de kloof tussen werknemers met veel en werknemers met weinig loopbaansteun door de werkgever dus niet te kunnen dichten.

We staan tenslotte stil bij de rol van loopbaan(on)tevredenheid. Loopbaantevredenheid heeft een negatieve invloed op zowel extern individueel loopbaanmanagement als op de deelnameintentie aan externe loopbaanbegeleiding. Loopbaanontevredenheid lijkt dus een 'trigger' voor extern loopbaaninitiatief. We merken op dat, in het huidige loopbaantijdperk waarin bedrijven niet langer werkzekerheid kunnen garanderen, ook tevreden werknemers baat 
hebben bij een meer proactieve houding en bij investeringen in hun mogelijkheden buiten het huidige bedrijf.

Tussen intern individueel loopbaanmanagement en loopbaantevredenheid vonden we geen relatie. Dit kan erop wijzen dat wie ontevreden is met zijn loopbaan geen extra moeite doet om de bedrijfsinterne inzetbaarheid te verruimen. Het is echter ook mogelijk dat loopbaantevredenheid en intern individueel loopbaanmanagement elkaar wederzijds beïnvloeden. Zo kan men uit ontevredenheid met de loopbaan in de interne inzetbaarheid investeren, wat op zijn beurt de loopbaantevredenheid positief beïnvloedt. Met onze dataset kunnen we deze mogelijkheid helaas niet onderzoeken.

Op basis van de resultaten van dit onderzoek kunnen we besluiten dat verschillende partijen een rol kunnen spelen in het ondersteunen van employability. Employability-investeringen door de ene actor blijken (de nood aan) employability-investeringen door een andere partij niet te verminderen. Het gevonden nuleffect van loopbaanmanagement door de organisatie op externe loopbaanbegeleiding indiceert dat deze instrumenten geen substituten zijn, maar deels op andere behoeften inspelen. Dit geeft ondersteuning voor het recht op externe loopbaanbegeleiding in Vlaanderen. Het nuleffect wijst echter ook op beperkingen van externe loopbaanbegeleiding als vangnet voor wie bij loopbaanmanagement door de werkgever uit de boot valt. Het verdient daarom aanbeveling bedrijven aan te moedigen loopbaanmanagement te voorzien voor alle werknemers. Deze aanbeveling wordt versterkt door de bevinding dat loopbaanmanagement door de organisatie individueel loopbaanmanagement lijkt te stimuleren.

We willen tenslotte wijzen op een aantal beperkingen van dit onderzoek. Een eerste beperking ligt in het feit dat we de intentie tot deelname aan externe loopbaanbegeleiding gemeten hebben. Deze keuze was noodgedwongen omdat de data verzameld werden in de opstartfase van het recht op externe loopbaanbegeleiding. Wil men echter een correcter beeld van de samenhang tussen loopbaanmanagement door de organisatie, individueel loopbaanmanagement en externe loopbaanbegeleiding, dan moet de analyse aangevuld worden met gegevens over de effectieve deelname aan externe loopbaanbegeleiding. Een tweede beperking is dat de loopbaanmanagementvariabelen werden gemeten door naar een aantal concrete praktijken te vragen. Hoewel het om praktijken gaat waarvan eerder onderzoek aantoonde dat ze waardevol zijn voor iemands inzetbaarheid (zoals het toekennen van een mentor of het uitpluizen van vacatures), hangt het nut van iedere activiteit deels af 
van het specifieke moment en de specifieke situatie waarin de persoon zich bevindt. Bovendien kunnen ook andere (niet bevraagde) activiteiten iemands inzetbaarheid positief beïnvloeden. Schalen met praktijkonafhankelijke items, zoals "Ik neem zelf de verantwoordelijkheid op voor mijn loopbaan" uit de recente career orientation index van Briscoe, Hall en DeMuth (in press), lijken daarom meer aangewezen. Tot slot rijst de vraag of onze bevindingen ook gelden in andere economische contexten. Om deze vraag te beantwoorden, is herhalingsonderzoek in andere landen nodig. $\mathrm{Nu}$ verschillende Westerse overheden met systemen van externe loopbaanbegeleiding experimenteren (OECD, 2004), lijkt dergelijk onderzoek uitermate relevant. 


\section{Referenties}

Anakwe, U., Hall, J. \& Schor, S. (2000). Knowledge-related skills and effective career management. International Journal of Manpower, 21, 566-579.

Bandura, A. (1986). Social foundations of thought and action: a social cognitive theory. New York: Prentice-Hall, Englewood Cliffs.

Boom, J.M. \& Metselaar, E.E. (2001). Determinanten van employability. Gedrag en Organisatie, 14, 21-33.

Bollérot, P. (2001). Two Actors in Employability: The Employer and the Worker. In P. Weinert (Eds), Employability - From Theory to Practice (pp. 51-90). New Brunswick, NJ : Transaction Publishers.

Bretz, R.D., Boudreau, J., Judge, T. (1994). Job search behavior of employed managers. Personnel Psychology, 47, pp. 275-301.

Briscoe, J., Hall, D. \& DeMuth, R. (in press). Protean and Boundaryless careers: an empirical exploration. Journal of Vocational Behavior.

Brown, J. (2001). The demand for adult guidance. Occasional Paper. Edinburgh: National Association for Educational Guidance for Adults.

Crant, J. (2000). Proactive behavior in organizations. Journal of Management, 26, 435-462.

Crites, J. (1969). Vocational psychology. New York: McGraw-Hill.

Dam, K. Van (2004). Antecedents and consequences of employability orientation. European Journal of Work and Organizational Psychology, 13, 29-51.

Dawis, R. \& Lofquist, L. (1984). A psychological theory of work adjustment. Minneapolis: University of Minnesota Press.

DeFillippi, R. \& Arthur, M. (1994). The boundaryless career: a competency based perspective. Journal of Organizational Behaviour, 15, 307-324.

Delsen, L. (1998). Zijn externe flexibiliteit en employability strijdig. Tijdschrift voor HRM, 2, $27-46$.

Eisenberger, R., Huntington, R., Hutchison, S. \& Sowa, D. (1986). Perceived organizational support. Journal of Applied Psychology, 71, 500-507.

Feyter, M. de, Smulders, P. \& Vroome, E. de (2001). De inzetbaarheid van mannelijke en vrouwelijke werknemers. Kenmerken van invloed. Tijdschrift voor Arbeidsvraagstukken, 17, 47-59.

Forrier, A. (2003). Temporary employment, employability and training. Leuven: Faculteit economische en toegepaste economische wetenschappen. 
Gaspersz, J. \& Ott, M. (1996). Management van employability: nieuwe kansen in arbeidsrelaties. Assen: Van Gorcum.

Griffeth RW, Gaertner S, Sager JK. (1999). Taxonomic model of withdrawal behaviors: The adaptive response model. Human resource management review, 9 (4): 577-590.

Griffin, B., \& Hesketh, B. (2003). Adaptable behaviours for successful work and career adjustment. Australian Journal of Psyhcology, 55, 2, pp. 65-74.

De Grip, A., van Loo, J., Sanders, J. (2004). The industry employability-index: taking account of supply and demand characteristics. International Labour Review, 143, 3, 211-233.

Guthrie, J., Coate, C. \& Schwoerer, C. (1998). Career management strategies: the role of personality. Journal of Managerial Psychology, 13, 371-386.

Hair, J.F.; Anderson, R.E. \& Tatham, R.L. (1995). Multivariate Data Analysis with Readings. New York: Macmillan Publishing.

Hatcher, L. (1998). A step-by-step approach to using the SAS system for factor analysis and structural equation modeling. Cary (N.C.): SAS institute.

Heijden, B. van der (2002). Individual career initiatives and their influence upon professional expertise development throughout the career. International Journal of Training and Development, 2002, 6, 54-79.

Hooft, E. Van, Born, M., Taris, T., Flier, H. Van Der \& Blonk, R. (2004). Predictors of job search behavior among employed and unempoyed people. Personnel Psychology, 57, 25-59.

Jiang, J., Klein, G. (2002). A discrepancy model of information system personnel turnover. Journal of Management Information Systems, 19, 249-272.

Joiner, T., Bartram, T. \& Garreffa, T. (2004). The effects of mentoring on perceived career success, commitment and turnover intentions. Journal of American Academy of Business, 5, 164-170.

Kidd, J., Jackson, C. \& Hirsch, W. (2003). The outcomes of effective career discussion at work. Journal of Vocational Behavior, 62, 119-133.

Killeen, J., White, M. (2000). The impact of career guidance on employed people.

Department for education and employment.

Killeen, J., White, M., Watts, A. (1992). The economic value of careers guidance. London: NICEC.

King, Z. (2001). Career self-management: a framework for guidance of employed adults. British journal of guidance and counseling, 29, 65-76.

King, Z. (2004). Career self-management: its nature, causes and consequences. Journal of Vocational Behavior, 65, 112-133.

Kline, R. (1998). Principles and practice of structural equation modeling. New York: Guildford. 
Kooiker, R. (2003). Marktonderzoek. Wolters-Noordhoff.

Kraimer, M., Seibert, S., Wayne, S. \& Liden, R. (2003). Examining employee performance and turnover intentions from a careers perspective. Paper presented at the 2003 Academy of Management, Seattle.

Maanen, J. Van \& Schein, E. (1979). Toward a theory of organizational socialization. In B. Staw (eds), Research in Organizational Behavior: Greenwich, CT: JAI Press.

Martins, L., Eddleston, K. \& Veiga, J. (2002). Moderators of the relationship between workfamily conflict and career satisfaction. Academy of Management Journal, 45, 399-409.

Maurer, T. \& Tarulli, B. (1994). Investigation of perceived environment, perceived outcome and person variables in relationship to voluntary development activity by employees. Journal of Applied Psychology, 79, 3-14.

OECD (2004). Career guidance and public policy. Bridging the gap. Paris: OECD.

Orpen, C. (1994). The effects of organizational and individual career management on career succes. International Journal of Manpower, 15, 27-37.

Raabe, B. \& Beehr, T. (2005). Antecedents and consequences of career self-management behaviors. Paper presented at the 2005 Academy of Management, Honolulu..

Rhoades,L. \& Eisenberger, R. (2002). Perceived organizational support: a review of the literature. Journal of Applied Psychology, 87, 698-714.

Sanders, J., de Grip, A. (2004). Training, task flexiblity and low-skilled workers' employability. International Journal of Manpower, 2004, 25, 1, 73-89.

Seibert, S., Kraimer, M. \& Crant, J. (2001). What do proactive people do? A longitudinal model linking proactive personality and career success. Personnel Psychology, 2001, 54, 845-874.

Stickland, R. (1996). Career self-management - Can we live without it? European Journal of Work and Organizational Psychology, 5, 4, 583-596.

Sturges, J., Guest, D., Conway, N., \& Mackenzie Davey, K. (2002). A longitudinal study of the relationship between career management and organizational commitment among graduates in the first ten years at work. Journal of Organizational Behavior, 23, 6, 731-748.

Sturges, J., Conway, N., Guest, D. \& Liefooghe, A. (2003). The psychological contract as a framework for understanding career management and commitment. Academy of Management best conference paper, CAR: G1-6.

Sturges, J., Conway, N., Guest, D. \& Liefooghe, A. (2005). Managing the career deal: the psychological contract as a framework for understanding career management, organizational commitment and work behavior. Journal of Organizational Behavior, 26, 821-838.

Tharenou, P. (1997). Managerial career advancement. In C.L.Coper \& I.T.Robertson (eds), International Review of Industrial and Organizational Psychology (pp. 39-93). Chichester, UK: John Wiley \& Sons. 
Verbruggen, M., Forrier, A., Sels, L. \& Vandenbrande, T. (2005). Draagvlak voor een recht op externe loopbaanbegeleiding. Een marktstudie. Leuven: Onderzoekscentrum Personeel \& Organisatie (TEW).

Watts, A.G. (2000). Career development and public policy. The Career Development Quarterly, 48, 301-312. 